材料組織のマッピンワー自動 分析・解析技術

\title{
材料組織の元素マッピング*
}

杉山昌章**

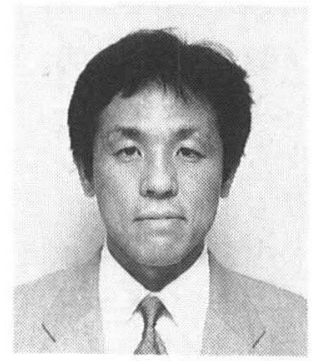

\section{Mapping Techniques of Element Distribution in Material Microstructure*}

\author{
by Masaaki SUGIYAMA**
}

キーワード：元素マッピング, 材料組織, 自動化, 解析技術, 電子プロー ブマイクロアナライザ, EPMA，溶接組織

\section{1. はじめに}

溶接技術における材料組織はどこまで解析できるのだ ろうか? 母材組成と異なる溶接金属を使用したり, 急速 加熱・冷却により母材組織を大きく変化させる可能性の あるこの技術分野では, 材料開発者ならずとも材料を構 成している元素が溶接過程で，どのように分布している のか，またどのような役割を果たしているのか，興味を 持たれる技術者も少なくないであろう。また割れの原因 を調べるために組織解析が行われるかもしれない。この ようなニーズに応えるために, 一方では組織の定量分析 化技術があり，他方では，組織における元素分布のマッ ピング技術がある、組織の元素マッピング像は,「百聞は 一見にしかず」の通り様々なイメージを抱かせるもので あり，その技法を簡単に紹介する.

元素マッピング技術の範疇では，その対象とする組織 のサイズにより必然的に分析手法は異なる。最も汎用的 に使われ，分析技術としての完成度も比較的高いのが, 電子プローブマイクロアナライザ（以下， Electron Probe Micro Analyzer : EPMA と略す) である. 分析 対象は原子番号 4 の $\mathrm{Be}$ から 92 の Uにまで及び, 軽元 素から重元素までほとんどの元素を検出可能であり, 分 析領域は $\mathrm{mm}$ オーダーから $\mu \mathrm{m}$ オーダーに及ぶので, 多 くの鉄鋼材料, 或いはそれらの溶接技術において, 十分 活用し得る装置性能を有している。もちろん表面に導電 性処理を工夫して, 金属材料に限らずセラミックスから 有機材料まで, 幅広い材料組織の元素マッピング像を得 ることが可能である。一方, 分析領域をより小さくし て, $\mu \mathrm{m}$ オーダーから $\mathrm{nm}$ オーダーでの微細組織の元素

*原稿受付 平成 11 年 9 月 20 日

**正貝新日本製鐵侏先端技術研究所 Nippon Steel Corp.
マッピング技術としては，電子顕微鏡を用いた元素マッ ピング技術がある，さらに原子レベルでの元素マッピン グ技術としては, 電界イオン顕微鏡において最近三次元 情報が得られるようになり，まさに実空間での三次元的 原子分布を再構築することが可能になっている，つま ク，現在の分析技術を活用すれば，肉眼で見える組織か ら，原子一個ずつが並んだ極微組織の世界まで，可視化 することが可能になったといえる。

さて本実用講座では， $\mu \mathrm{m}$ オーダーでの元素マッピン グが得意な EPMA 技術を中心に，簡単な技術解説を行 う. 特に定量性の議論ではなくて，「元素マッピングで 何を見ているのか」が判るように解説するので，定量性 (点分析)をも含めた EPMAの全般技術について興味の ある方は，良書 ${ }^{1)}$ があので参照して頂きたい。

\section{2. よ゙のようにして元素分析をするか?}

マッピング技術に踏み込む前に，元素分析をする方法 について考えてみる。ある点での元素分析ができれば， 何らかの方法でそれを平面 (二次元)的に拡張すればマッ ピング像となるからである，最も簡便な方法は，電子線 を磁界レンズ（電磁石の一種）を用いて収束し, 測定し たい材料組織に当てることである．電子線でなくても X 線やイオン線でも分析は可能であるが，1 $1 \mu \mathrm{m}$ 以下に容 易に収束できるのは電子線だけである，さて，電子線を 当てた時には, 図 1 に示すようにオージェ電子, 反射電 子, 二次電子, 特性 X 線などが, 電子と物質との相互作 用の結果として発生する。これらの中で, オージェ電子 と特性 X 線は相互作用を起こした元素の種類に特徵的 なエネルギーを持つので，これらを利用して元素分析を 行うことができる．反射電子なども定性的には原子番号 を反映するので組成像が得られるが，一元素ずつを識別 するような精度はない.オージェ電子は数十 $\mathrm{nm}$ 程度し 
か材料中を透過できないので，極表層の元素マッピング 像を得るのに利用される。本講座では, 数 $\mu \mathrm{m}$ の深さ情 報を持つ特性 X 線に的を絞り，説明していく。

\section{3. 試料に電子線を当てたときに，どこまでの 情報が得られるのか?}

特性 X 線の発生原理の辣細は専門書2)に譲るが, 電子 線が当たって励起した原子が，高いエネルギー準位から 低いエネルギ一準位に自身の電子を落とす時に発生させ るのが特性 X 線である.さてて「試料のどこからの情報を 得ているか」を考えるときに重要なのは，どこまで入射 電子線が入り込んでいるかという事と, どこから検出し ているX 線が発生しているかである。

まず，入射する電子線について考える，通常電子線の 加速電圧は 5 30 kV 程度であるが, 試料内部で電子が エネルギーを失わずに飛行できる距離（平均自由行程）は $30 \mathrm{kV}$ の加速電子でもたかだか数十 nmである.これでは

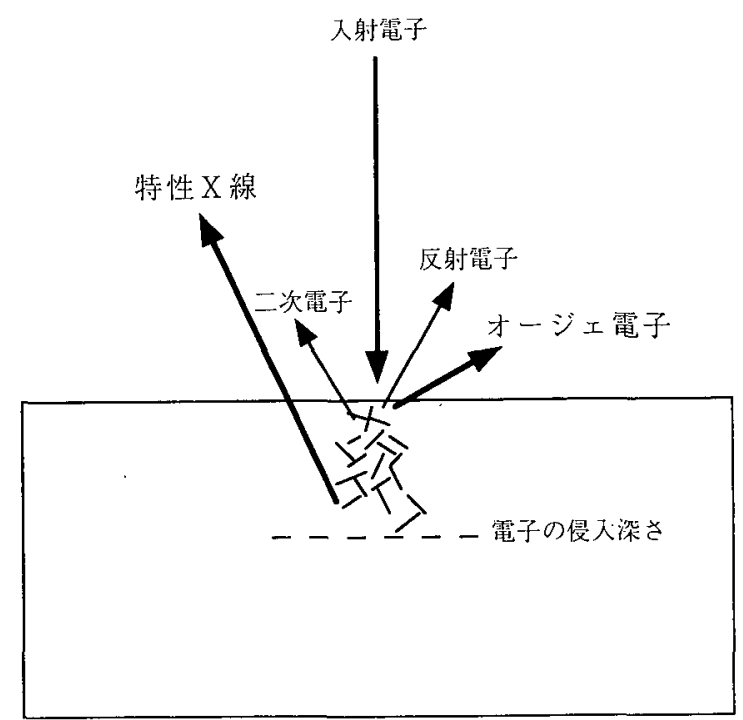

図 1 試料に電子が入射した時に発生する主な電子，X 線を示す 模式図
ほとんど電子が試料に入らないことになってしまう。しか し実際の試料中では，入射してきた電子は次から次へと他 の電子をはじき飛ばして，エネルギーを失いながらも数 $\mu \mathrm{m}$ 程度は伝播しながら拡散していく(カスケード現象)の で大丈夫である.アルミニウムなどの軽い材料の方が，鉄 などの重い材料に比へてて, 電子は梁くまで浸透していくこ とになる，拡散モデルを利用して最大深さが計算されてい る1が, 加速電圧 $30 \mathrm{kV}$ の場合, $\mathrm{Al}$ で約 $8 \mu \mathrm{m}, \mathrm{Cu}$ で約 $2.8 \mu \mathrm{m}$ ，そして，加速電圧 $10 \mathrm{kV}$ の場合， $\mathrm{Al}$ で約 1.3 $\mu \mathrm{m}, \mathrm{Cu}$ で約 $0.5 \mu \mathrm{m}$ という值が報告されている．かなり 元素ごとにその依存性が違うことが判る.

次に，発生したX 線の試料からの脱出に関して考えて みる，電子に比べて X 線は波長も長く，数 $\mu \mathrm{m}$ という哚 さで発生した特性 X 線でも試料中を通過して検出器に到 達することができる。なお元素に応じた X 線発生領域の 梁さが計算されている1ので，その代表例を表 1 に示して おく，同じ元素を分析する場合でも，母材元素の種類（密 度）に大きく依存して，その発生領域の深さが違うことが 良く判る.また $\mathrm{Zn} の \mathrm{~L} \alpha$ 線のみを分析する際には $5 \mathrm{kV} の$ 加速電圧とするなど, 分析元素の特性 X 線のエネルギーに 応じて，最適な加速電圧も決定されることになる。

\section{4. 電子プローブマイクロアナライザ装置の概略}

特性 X 線を検出して元素分析をする本技術の歴史は 古く，1949 年にフランスの Castaing が実用装蹎として の開発に成功している．日本でも 1960 年代に積極的に 開発が進み, 1970 年代に入ると電算機結合型の装置が普 及し，自動計測化の開発が行なわれた。この頃の EPMA の測定範囲は約 $0.2 \mathrm{mmx} 0.2 \mathrm{~mm}$ であり，試料全体の元 素分布を把握するという目的には到達していなかった. 1980 年に入り，鉄鋼材料組織の中心偏析や介在物解析 のために，新日本製鉄 (株)では EPMAによる元素マッ ピング化技術の開発に着手し，日本電子(株) と共同で, 数時間で元素マッピングの得られる EPMAの開発に成 功しだ! これが今日の画像マッピングに使われている EPMAの原型であり，そのデータ収集部の構成図を図 2

表 1 母材密度と分析元素に基づき計算された幾つかの元素の特性 X 線の最大発生深さ位置一例

\begin{tabular}{|c|c|c|c|c|c|}
\hline 母材 & 母材密度 & 特性 X 線 & エネルギー & 加速電圧 & 最大 X 線発生深さ \\
\hline $\mathrm{Fe}$ & $7.86 \mathrm{~g} / \mathrm{cm}^{3}$ & $\mathrm{Zn}-\mathrm{K} \alpha$ & $9.657 \mathrm{keV}$ & $20 \mathrm{kV}$ & 約 $0.9 \mu \mathrm{m}$ \\
\hline $\mathrm{Fe}$ & $7.86 \mathrm{~g} / \mathrm{cm}^{3}$ & $\mathrm{Zn}-\mathrm{L} \alpha$ & $1.200 \mathrm{keV}$ & $5 \mathrm{kV}$ & 約 $0.1 \mu \mathrm{m}$ \\
\hline $\mathrm{Fe}$ & $7.86 \mathrm{~g} / \mathrm{cm}^{3}$ & $\mathrm{P}-\mathrm{K} \alpha$ & $2.142 \mathrm{keV}$ & $20 \mathrm{kV}$ & 約 $1.2 \mu \mathrm{m}$ \\
\hline $\mathrm{Fe}$ & $7.86 \mathrm{~g} / \mathrm{cm}^{3}$ & $\mathrm{P}-\mathrm{K} \alpha$ & $2.142 \mathrm{keV}$ & $5 \mathrm{kV}$ & 約 $0.8 \mu \mathrm{m}$ \\
\hline $\mathrm{Mg}$ & $1.74 \mathrm{~g} / \mathrm{cm}^{3}$ & $\mathrm{Zn}-\mathrm{K} \alpha$ & $9.657 \mathrm{keV}$ & $20 \mathrm{kV}$ & 約 $4.0 \mu \mathrm{m}$ \\
\hline $\mathrm{Mg}$ & $1.74 \mathrm{~g} / \mathrm{cm}^{3}$ & $\mathrm{Zn}-\mathrm{L} \alpha$ & $1.200 \mathrm{keV}$ & $5 \mathrm{kV}$ & 約 $0.5 \mu \mathrm{m}$ \\
\hline $\mathrm{Al}$ & $2.69 \mathrm{~g} / \mathrm{cm}^{3}$ & $\mathrm{Cu}-\mathrm{K} \alpha$ & $8.978 \mathrm{keV}$ & $30 \mathrm{kV}$ & 約 $7.1 \mu \mathrm{m}$ \\
\hline $\mathrm{Al}$ & $2.69 \mathrm{~g} / \mathrm{cm}^{3}$ & $\mathrm{Cu}-\mathrm{K} \alpha$ & $8.978 \mathrm{keV}$ & $20 \mathrm{kV}$ & 約 $3.1 \mu \mathrm{m}$ \\
\hline $\mathrm{Al}$ & $2.69 \mathrm{~g} / \mathrm{cm}^{3}$ & $\mathrm{Cu}-\mathrm{K} \alpha$ & $8.978 \mathrm{keV}$ & $10 \mathrm{kV}$ & 約 $0.2 \mu \mathrm{m}$ \\
\hline
\end{tabular}


に示す。なおマッピング時の各分析スポットあたりの測 定時間は $10 \mathrm{~ms}$ オーダーという極短時間であるため，効 率の高い分光結晶の開発が並行して行われた.

分析対象としての試料サイズであるが， EPMAはか なり大きな試料ステージ空間を持っているので，100 $\mathrm{mm} \times 100 \mathrm{~mm}$ 程度で高さが $20 \mathrm{~mm}$ 程度の試料を容易 に装填することができる，大型ステージを用いれば， 100 $\mathrm{mm}$ 高さ程度でも装填することができるので，試料サイズ に対する制約はほとんどないと考えて良いであろう。

\section{5. 元素マッピングのためのビームスキャン方法}

面分析を行なうためには，電子線を二次元的にスキャ ンする方法と，電子線を止めて試料の方を二次元的にス キャンする方法の 2 つが容易に考えられる，微小領域を 高分解能で元素マッピングしたい時は電子線をスキャン させ,やや面分解能は落ちてもよいから広範囲を元素 マッピングしたい時は試料ステージをスキャンさせる。 通常は両者を組み合わせて，低倍率から高倍率へと目的 とする組織の元素マッピング像を得ていく，ところで， 通常試料に当てる電子線の断面は円形であるので，その ままスキャンさせると図 3 (a) に示すように分析すべき 領域に吵間がでてしまう。知間がでないようにするには ビーム径を互いに重なるように大きくすればよいが，こ の場合は重なり効果を考慮してマッピング像を解析しな ければいけない。これらを避けるための一案としては， 電子線を $7 \mathrm{~nm}$ 程度に非常に細く収束させて高速でライ ン状にスキャンさせて線状ビームを作る方法がある。こ の方法では, 目的画素に応じて数 $\mu \mathrm{m}$ 長さの線状ビーム を作り，次に試料ステージをスキャンさせて元素マッピ
ング像を得る．画素間に隙間のないデータが採取できる のが特徵である、この原理図を図 3 (b) に示す。なお画 素サイズについては目的とする組織に応じて変えること になるが，例えば $5 \mu \mathrm{mx} 5 \mu \mathrm{m}$ の角型画素を用いて， $\mathrm{x}$ 方向，y 方向に 500 点ずつ測定すれば， $2.5 \mathrm{mmx} 2.5 \mathrm{~mm}$ の領域のマッピング像が得られる.なおここでの画素と は X 線強度を積算していく基本単位のことであり，分析 点 1 点に封応する。それゆえ分解能をあげるには，例之 ば画素を $2 \mu \mathrm{mx} 2 \mu \mathrm{m}$ というように次第に小さくして いけば良いのである。また 1 画素 (1 分析点)での電子線 の総滞在時間が, マッピング像を得る時の総時間を決め ていく，通常は $50 \mathrm{msec}$ 標準としている。ところで $500 \times 500=25$ 万点というようにマッピングは数万点に 及ぶ多点測定であり，一枚の像を得るのに通常数時間を 必要とする。この测定時間中の照射電流を如何に一定に 保つか，という事が精度向上において重要な課題であっ たことを付け加えておく、エレクトロニクスの進歩がこ れらを可能とし，現在では 2 日間位かけた長時閒測定を も安定的に行なえるようになっている。

\section{6. 発生した特性 X 線の検出方法}

元素マッピングの方法について簡単に述べたが, 分析 对象や分析精度を考慮して，どのような検出手段を用い るかを次に述べる，発生した特性 X 線を回折結晶によ り分光し，その波長の違いに基づいて元素分析を行なう 波長分散方式と， Li をドープした Si 半導体検出器を用 いて，特性 X 線のエネルギーに応じて発生する電子の 量を計数するエネルギー分散方式の二つに大別できる. 最近の EPMA 装置には，この二方式の検出器が一緒に

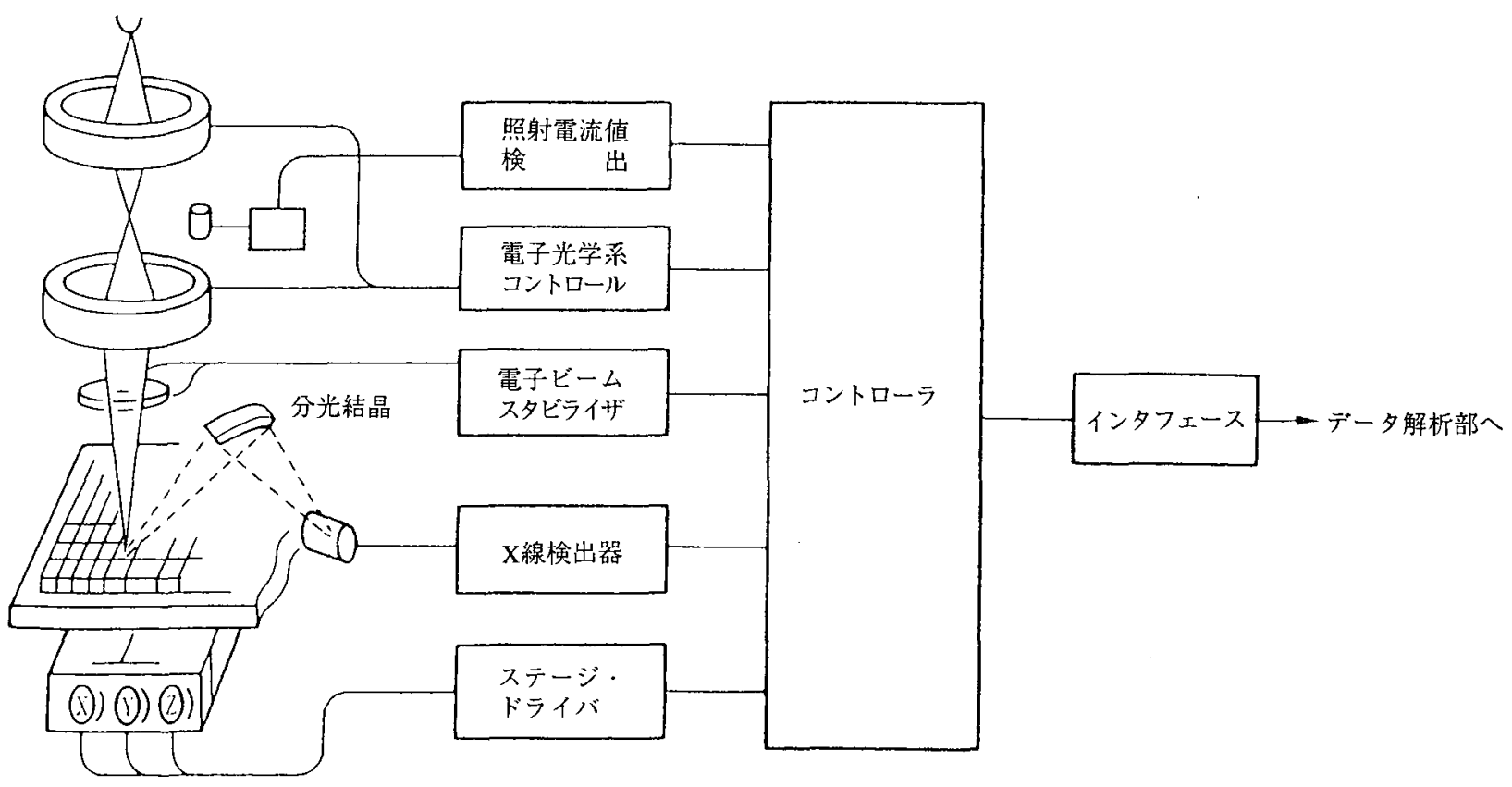

图 2 自動元素マッピングを可能としたEPMA 装凅データ収集部の構成図 

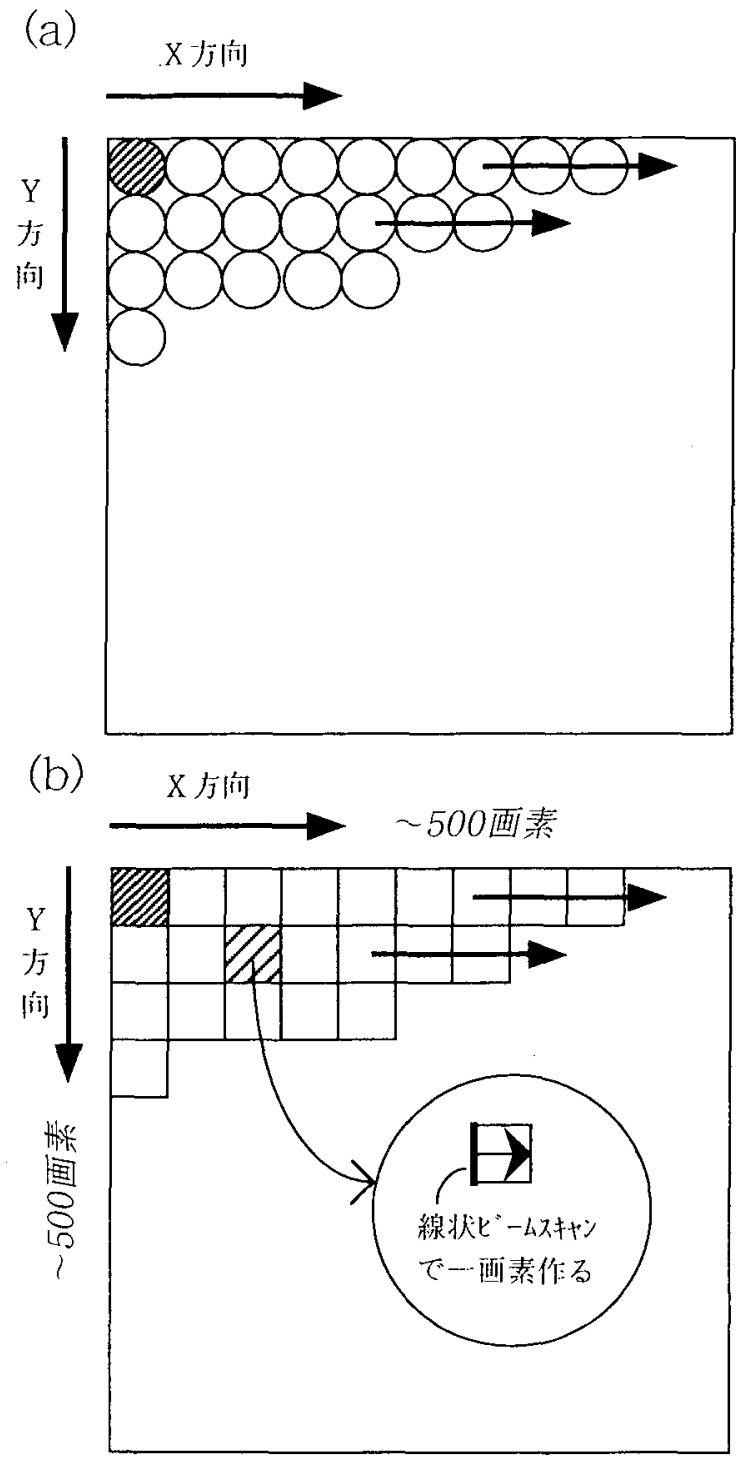

図３元装マッピング時のビームスキャン万法を示す模式図

(a) 円形ビームスキャン方法

（b）線状ビームスキャン方法

取り付けられるようになったので，その長所と短所を十 分に知っておくことが大切である。波長分散方式とは, 图 4 に示すように, 試料から発生した特性 X 線を, 湾 曲型の分光結晶を用いて回折させて検出器に集光させる 方法である. 分光結晶と検出器が同時に相対的に駆動 し，それらと試料の軌跡はローランド円上を動く。詳細 は参考文献"に謴るが, 長所は, 軽元素や微量元素に対 する検出感度が高く, 定量分析の精度が高いこと, 近接 するX 線を分離する能力, 即ち分解能が高いことであ る。な打検出する元素に併せて, 最適な感度が得られる 分光結晶を予如設定することが重要である，短所は，試 料に凹凸がある場合, X 線発生位置と分光結晶と検出器 の相対位置がローランド円の条件を満足しなくなり䛊差 が大きくなることである。そこで予为測定試料を鏡面研 磨しておく必要がある。

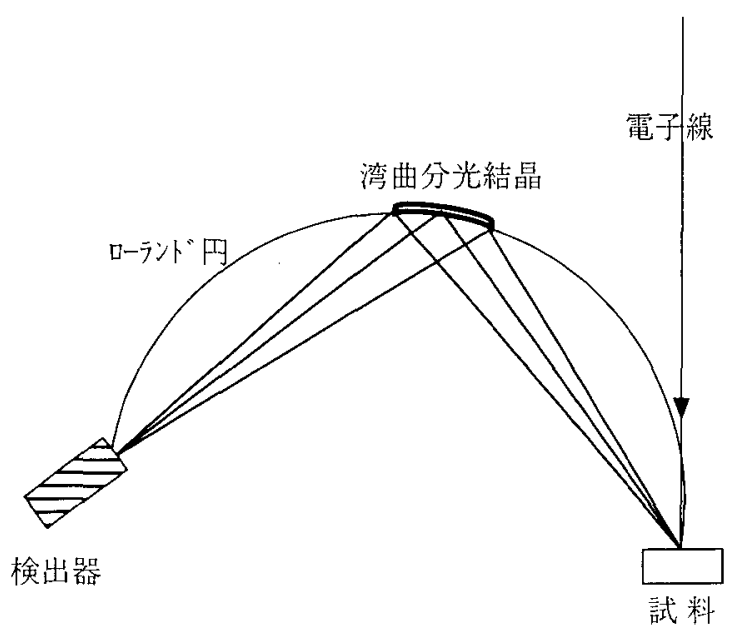

図 4 波長分散方式での試料と回折結晶と検出器の幾何学的関係 を示す模式図

一方, エネルギー分散方式では, 試料に検出器を近づ けて発生した特性 X 線を集める。この場合, 検出器と試 料との相対角度により分析感度が変わってくるが, 長所 は多元素が同時に収集できる事と，僅かな照射電流で分 析ができるので試料污染が少ない事である．また少々表 面が凹凸であっても構わないことである，但し分析箇所 が局所的に凹凸部となっており，発生した特性 X 線が検 出器に届くまでにその壁にぶつかってしまうような幾何 学形状を持つ試料では，いずれの方法によらず，検出誤 差は大きくなるので注意が必要である。エネルギー分散 方式の短所は，波長分散方式に比へて定量性に劣ること である.一般には，両者をうまく組み合わせて測定す る，例之ば，軽元素や精度の求められる重要な成分，或 いは微量元素成分を波長分散形 X 線分光器に割り当て, 重元素でかつ多量成分をエネルギ一分散形 X 線分光器 に割り当てて测定し，目的の元素マッピング像を得る. 最新のEPMA では，このような方法で同時に 10 元素以 上のマッピング像を得ることが可能になっている．もち ろん繰り返し自動測定を行之ば，さらに多数の元素につ いてのマッピング像が得られることは言うまでもない。

\section{7. どのような元素マッピング像が得られるか}

軽元素から重元素まで, 同時に 10 種類以上の元素を同 時に計测できることを説明してきたので，测定例を活用 して，実際にどのようなマッピング像が得られるかを説 明する。図 5 はスケール直下で内部酸化している鋼板表 層部の断面組織のマッピング像である. 10 元素以上の元 素を同時测定し，それぞれの計測強度に応じた濃度階調 を疑似力ラー表示する。そしてその中から特徴的な元素 として，ここでは $\mathrm{Fe}, \mathrm{O}, \mathrm{Si}, \mathrm{Mo}$ を選び，それらの疑似 カラー像を $2 \times 2$ の画像としてプリントアウトしたもの である，各元素の変化が明暸に分かるように，一元素ご 


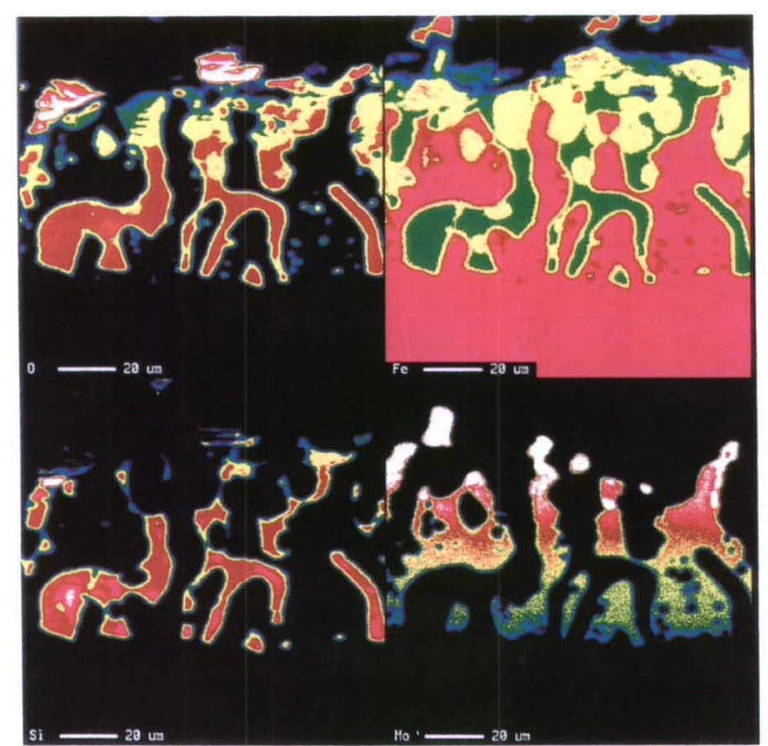

図 5 鉄鋼のスケール内部酸化層組織のマッピング像での $\mathrm{O}$ $\mathrm{Fe}, \mathrm{Si}, \mathrm{Mo} の$ 各マッピング像

とに最適な疑似カラー表示（赤；濃度大）となる条件を 調整している。図 5 の 4 枚のマッピング像を眺めること により, Fe と Oのマッピング像の重なり部分が内部酸 化領域であることが分かる。そして Si マッピング像で も同じ部分の強度が強いことから, $\mathrm{Fe}-\mathrm{Si}-\mathrm{O}$ 系の内部酸 化層であることが分かる。一方，Moマッピング像は $\mathrm{Fe}$ マッピング像と重なり，Oマッピング像と一致しないこ とから，鋼板表層部に濃化してきていることが分かる. このように，組織の元素マッピング情報は，そこで起き ている現象を理解する上で非常に有効な知見となる.

\section{8. 元素マッピング像のデータ解析処理について}

各元素のマッピング像を得ると同時に，そこに含まれ ている多くの情報をデー夕解析することにより新たな デー夕を抽出することも可能である，例えば二つ，或い は三つの元素を決め, それぞれをグレースケール階調に 変換した後に, 赤 $(\mathrm{R})$, 緑 $(\mathrm{G})$, 青 $(\mathrm{B})$ の光の三原色 に割り当てる。そしてこれらを組み合わせることによ $\eta$, 各元素間の相関関係や，合金相の様子が視覚的に判 るようになる。図 6 は，低炭素鋼（Fe-0.13\% C-0.32\% $\mathrm{Si}-1.52 \% \mathrm{Mn}-0.016 \% \mathrm{P})$ を一方向に凝固させた後，約 $1500^{\circ} \mathrm{C}$ から $2.7^{\circ} \mathrm{C} /$ 分の冷却速度で水冷し, 試料の縦断 面の分析を行ったものである， Mnを赤で， P を緑で 示した。すると両者が共存する部分は黄色となる. 図6 を見ると, $1480^{\circ} \mathrm{C}$ 以上では $\mathrm{Mn}$ と $\mathrm{P}$ の分布が完全に一致 し黄色模様にマッピングされているのに対して, $\delta \rightarrow \gamma$ 変態後は黄色部分が消滅している。即ち凝固過程を通じ て, $\delta \rightarrow \gamma$ 変態とともに溶質元素の再分配が起きている ことが判った例である。このようにカラーマッピング像

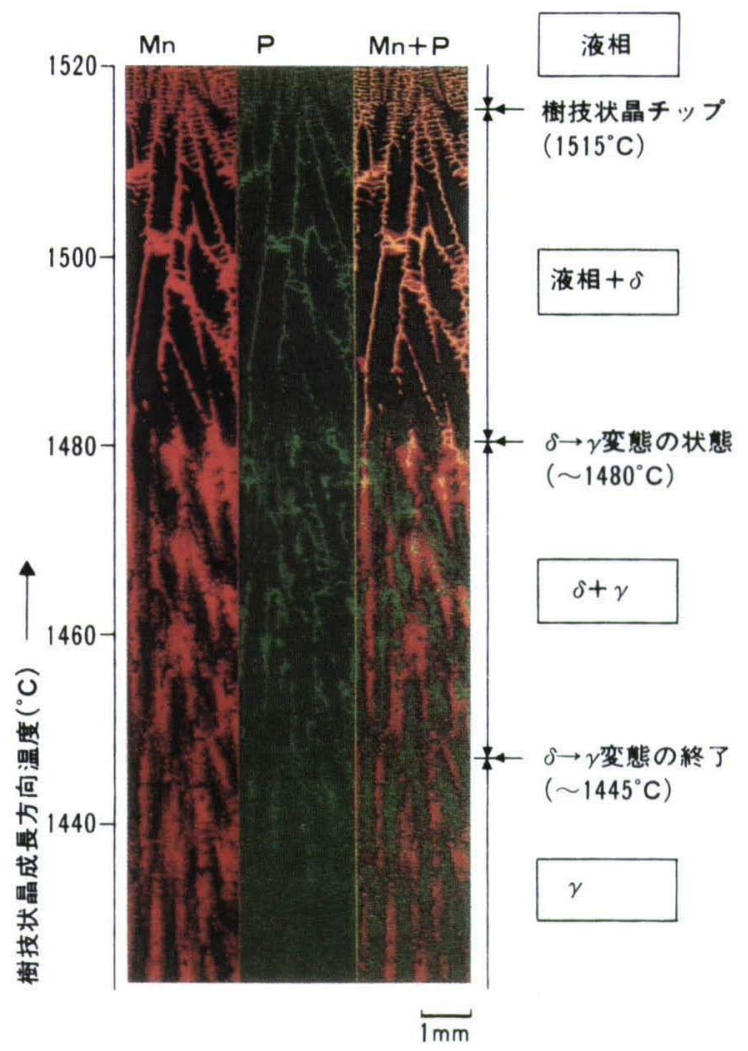

図 6 鉄鋼の凝固過程の $\mathrm{Mn}$ と $\mathrm{P}$ の分布変化を示すマッピング 像. $\mathrm{Mn}$ を赤色， $\mathrm{P}$ を緑色で割り当て，それらを重ねあわせ たマッピング処理像を, 組写真の一番右に表示

の組み合わせを利用して，さまざまさ組織変化を解明す ることが可能である．また元素マッピング像は，可視化 という視点だけでなく，特定元素からなる粒子のサイズ や分布の解析, 或いは, 特定の元素が濃縮している部分 の線分析解析なども定性的に可能であり，様々なデー夕 解析が工夫されている技術分野である.

\section{9. ま とめ}

EPMA 法を中心に, 元素マッピング技術について簡単 に解説した。 マッピング像は組織の具体的なイメージを 我々に与えてくれるので，一度得られれば，非常に説得 力あるものとなる．溶接技術分野においても，介在物を 利用した組織の微細化や，新しい固相接合法，また割れ の原因となる偏析や介在物の解析などに, 元素マッピン グ技術が適用されていくことを期待する.

\section{参 考 文 献}

1) 副島啓義：電子線マイクロアナリシス, 日刊工業新䦘社 (1987).

2) 大西孝治, 堀池靖浩, 吉原一紘：固体表面分析 I, 講談社 (1995).

3) 浜田広樹, 田口勇：新 $\mathrm{X}$ 線マイクロアナライザー(CMA) に上る鉄鋼㧋態分析，製鉄研究，323（1986） 15-23. 